\title{
Endogenous hormonal equilibrium linked to bamboo culm development
}

\author{
H.Y. Wang ${ }^{1 *}$, K. Cui ${ }^{*}$, C.Y. He ${ }^{2}$, Y.F. Zeng ${ }^{2}$, S.X. Liao ${ }^{1}$ and J.G. Zhang ${ }^{2}$ \\ ${ }^{1}$ Research Institute of Resources Insects, Chinese Academy of Forestry, \\ Kunming, China \\ ${ }^{2}$ State Key Laboratory of Tree Genetics and Breeding, Research Institute of Forestry, \\ Chinese Academy of Forestry, Beijing, China \\ *These authors contributed equally to this study. \\ Corresponding author: J.G. Zhang \\ E-mail: zhangjg@caf.ac.cn
}

Genet. Mol. Res. 14 (3): 11312-11323 (2015)

Received March 20, 2015

Accepted July 13, 2015

Published September 22, 2015

DOI http://dx.doi.org/10.4238/2015.September.22.25

ABSTRACT. Moso bamboo (Phyllostachys heterocycla) is the most important bamboo species in China and is famous for its fast-growing culms. To investigate the possible relationship between internode development and endogenous hormones, the concentrations of indole-3-acetic acid $(I A A)$, zeatin riboside ( $Z R)$, gibberellins $\left(G_{3}\right)$, and abscisic acid (ABA) were analyzed in culm samples from plants at different developmental stages during a single growing season and, at the same time, anatomical structure was closely monitored. Cell division was the dominant process in internode development during early development, while cell elongation predominated at later stages. There was a negative correlation between the rates of cell division and cell elongation. The four endogenous hormones (IAA, ZR, GA 3 , and $A B A$ ) displayed fluctuations in their levels at different developmental stages but their peak activities were not synchronous. Cell division rate had a significant positive correlation with ZR concentration. Cell elongation had a significant positive correlation with the ratio of promoting hormones (IAA, $\mathrm{GA}_{3}$, and $\mathrm{ZR}$ ) to inhibitory hormone (ABA) concentrations. We conclude 
that hormonal equilibrium might regulate the division and elongation of bamboo culms.

Key words: Phyllostachys heterocycla; Internode elongation; Plant hormones; Cell length; Cell division

\section{INTRODUCTION}

Bamboo species are among the fastest-growing lignocellulose-abundant plants on Earth; over 1500 species of bamboo are distributed worldwide (Chen et al., 2010). The growth rate of bamboo is very unusual in which developing bamboo culms can reach their final height of several meters $(5-20 \mathrm{~m})$ within the relatively short period of two to four months (Magel et al., 2006). Some of the bigger bamboos, such as Guaduaan gustifolia, can produce about $500 \mathrm{~cm}^{3}$ of cell wall substance per day, amounting to nearly $0.1 \mathrm{~m}^{3}$ biomass for the entire culm (Magel et al., 2006). To our knowledge, there is no other group of plants with such a rapid growth rate. Although considerable research has been carried out into bamboo growth (Cui et al., 2012; Peng et al., 2013), the mechanism of this fast growth rate remains unknown.

The nature of the mechanisms that control the size and shape of organs is an important but still unanswered question of developmental biology. Two factors determine the size of mature organs: cell number and cell size (Bundy et al., 2012). Plant hormones are natural compounds with the ability to affect physiological processes, particularly in the area of growth (Nemhauser et al., 2006), at concentrations far below those where either nutrients or vitamins can affect these processes (Davies, 2010). Plant hormones have an important role in the regulation and coordination of cell proliferation and cell elongation. For example, cytokinins are implicated in the regulation of cell proliferation (Higuchi et al., 2004; Nishimura et al., 2004), while gibberellins, brassinosteroids, and auxins control both cell proliferation and cell elongation (Achard et al., 2009; Jurado et al., 2010). Bartrina et al. (2011) found that cytokinins play a key role in reproductive development (i.e. stem cell niche, cellular differentiation, and flower organ size) in Arabidopsis thaliana. PérezJiménez et al. (2014) reported that endogenous hormonal content affects somatic organogenesis capacity in peach. The concentration of endogenous IAA and the ratio among hormones influences cambial activity in some woody trees (Uggla et al., 1998, 2001; Mwange et al., 2005).

Moso bamboo (Phyllostachys heterocycla) is the most important bamboo species in China. It is the most widely distributed with the largest planting area (over two-thirds of the total planted bamboo area) and has the highest economic value in China (Peng et al., 2010). In this study, we used both microscopic analysis of anatomy and enzyme-linked immunoassay (ELISA) to investigate dynamic changes during internode elongation and the influence of four endogenous hormones on Moso bamboo growth over a single growth season. The relationship between internode elongation and endogenous hormone concentrations was examined.

\section{MATERIAL AND METHODS}

\section{Plant material}

Culm tissue was sampled in spring of 2013 from a natural population of $P$. heterocycla growing in the Dagang-Mountain Nature Reserve in Jiangxi Province of China $\left(27^{\circ} 30^{\prime}-27^{\circ} 50^{\prime} \mathrm{N}\right.$, 
$\left.114^{\circ} 30^{\prime}-114^{\circ} 45^{\prime} E\right)$. Dagang-Mountain Nature Reserve was established in 2005 . The Fenyi County government issued permission for the establishment of the Dagang-Mountain Nature Reserve and is responsible for its maintenance. The reserve is mainly a protected forest ecosystem (i.e., natural Chinese fir plantation and masson pine plantation). Field sampling in the reserve was approved by the Fenyi County government. All samples were collected in the same growing season. Nine developmental stages were defined based on the heights above ground of individual plants: 0.05 , $0.20,0.50,1.00,2.00,3.00,6.00,8.50$, and $12.00 \mathrm{~m}$, and named as G1, G2, G3, G4, G5, G6, G7, $\mathrm{G} 8$, and G9, respectively. Each culm was divided by an equal division method into three portions, namely basal, middle, and top regions, according to height (Figure 1A). Then, three internodes were collected separately including the first internode in the basal region, the longest internode of the middle region, and the uppermost internode of the top region. Three biological replicates were cut from culm tissue located in the basal part of each collected internode of plants of different stages. Part of each sample was immediately frozen in liquid nitrogen and stored at $-80^{\circ} \mathrm{C}$ until analysis, while the remainder was placed in a buffer and processed for microscopic analysis as described below.
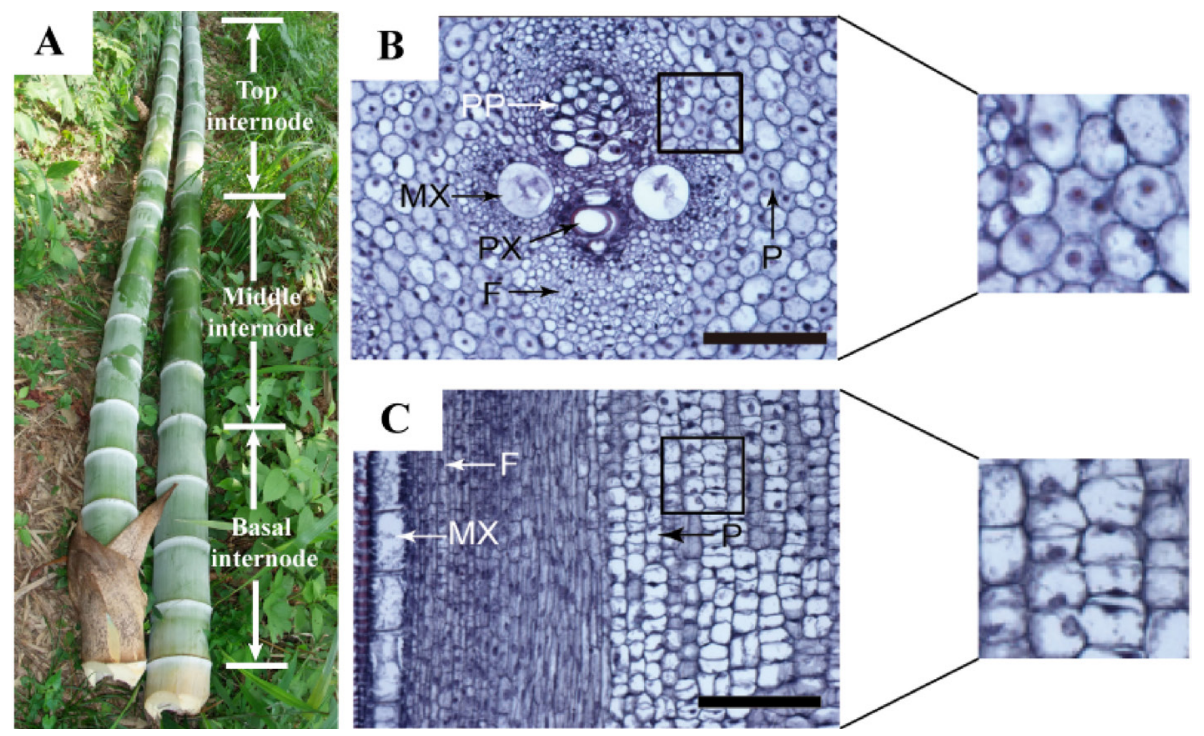

Figure 1. Histological sections of culm development in Phyllostachys heterocycla. The protocol for partitioning each culm into three regions is illustrated in (A): at each developmental stage, the culm was divided into three segments of equal height. During culm development, variations in parenchyma cells are representative and are comparable across stages. Thus, to compare cell division and elongation at different developmental stages and in different culm regions, the number of parenchyma cell nuclei in transverse section (B) and parenchymal cell lengths in longitudinal section (C) were measured microscopically. At each developmental stage, measurements were made from over 50 microscopy fields. $\mathrm{CN}=$ cell nuclei; $\mathrm{F}=$ fiber cells; $\mathrm{MX}=$ metaxylem; $\mathrm{P}=$ parenchyma cells; $\mathrm{PP}=$ protophloem; $\mathrm{PX}=$ protoxylem. Scale bars: $100 \mu \mathrm{m}$. The areas within the square boxes are shown enlarged in the right panel.

\section{Sectioning and light microscopy}

Tissue samples of approximately $0.5 \mathrm{~cm}^{3}$ volume were fixed in FAA (a mixture of $50 \%$ ethanol, acetic acid and formaldehyde, 18:1:1 v/v/v) and degassed using an aspirator pump. The 
tissues were dehydrated through a graded ethanol series $(50,70,85,95$, and $100 \%$ ethanol for $2 \mathrm{~h}$, respectively) and embedded in paraffin. Eight $\mu \mathrm{m}$ thick transverse and longitudinal sections were cut from the fixed cubes using a sliding microtome (LEICA DM 2135, Germany). After dewaxing and rehydration, the sections were stained first with a $1 \%$ safranin and then with $0.1 \%$ Fast Green. The sections were viewed using a Zeiss Axiolmager light microscope (Zeiss, Jena, Germany) and digital images were captured and analyzed using the Zeiss Axio Vision 4.6 w digital image analysis system.

\section{ELISA}

The methods for extraction and purification of endogenous hormones (IAA, GA, ZR, and ABA) were modified from those described by Yang et al. (2001) and Wang et al. (2000). The ELISA kits used for estimation of hormone levels were purchased from the China Agricultural University (Beijing, China). Culm tissue samples of approximately $0.5 \mathrm{~g}$ were ground in an ice-cooled mortar in $5 \mathrm{~mL} 80 \%(\mathrm{v} / \mathrm{v})$ methanol extraction medium containing $1 \mathrm{mM}$ butylated hydroxytoluene and $100 \mathrm{mg}$ polyvinylpyrrolidone (PVP) per gram fresh material. The extract was incubated at $4^{\circ} \mathrm{C}$ for $4 \mathrm{~h}$ and centrifuged at $1000 \mathrm{~g}$ for $15 \mathrm{~min}$ at the same temperature. The supernatant was passed through a Chromosep C18 column (C18 Sep-Park Cartridge, Waters Corp., Millford, MA, USA) that had been prewashed with $1 \mathrm{~mL} 80 \%$ methanol. Hormone fractions were eluted with $5 \mathrm{~mL}$ $100 \%$ methanol, $5 \mathrm{~mL}$ ether, and $5 \mathrm{~mL} 100 \%$ methanol and dried under $\mathrm{N}_{2}$; the samples were then dissolved in $2 \mathrm{~mL}$ PBS, $\mathrm{pH} 7.5$, containing $0.1 \%$ Tween 20 and $0.1 \%$ gelatin prior to ELISA. Mouse monoclonal antibodies against IAA, GA,$Z R$, and ABA, and IgG horseradish peroxidase were produced at the Phytohormones Research Institute (China Agricultural University, Beijing, China). ELISA was performed on a 96-well microtitration plate. Each well on the microtitration plate was coated with $100 \mu \mathrm{L}$ coating buffer $\left(1.5 \mathrm{~g} / \mathrm{L} \mathrm{Na}_{2} \mathrm{CO}_{3}, 2.93 \mathrm{~g} / \mathrm{L} \mathrm{NaHCO}\right.$, and $0.2 \mathrm{~g} / \mathrm{L} \mathrm{NaN}, \mathrm{pH}$ 9.6) containing $0.25 \mu \mathrm{g} / \mathrm{mL}$ antigens. The coated plates were incubated for $3 \mathrm{~h}$ at $37^{\circ} \mathrm{C}$ in a moist environment in the dark. After washing three times with $0.1 \%$ Tween 20 in $\mathrm{PBS}, \mathrm{pH} 7.4$, each well was filled with $50 \mu \mathrm{L}$ antibody $(20 \mu \mathrm{g} / \mathrm{mL})$ against IAA, GA,$Z R$, or ABA. Then, $50 \mu \mathrm{L}$ of tissue extracts, or IAA, $\mathrm{GA}_{3}, \mathrm{ZR}$, and $A B A$ standards $(0-2000 \mathrm{ng} / \mathrm{mL}$ dilution range) were filled.

The plate was incubated for $0.5 \mathrm{~h}$ at $37^{\circ} \mathrm{C}$ and then washed as above. One hundred microliters of $1.25 \mu \mathrm{g} / \mathrm{mL}$ lgG-horseradish peroxidase substrate were added to each well and incubated for $0.5 \mathrm{~h}$ at $37^{\circ} \mathrm{C}$. The plate was rinsed five times with the $0.1 \%$ Tween 20 in PBS and $100 \mu \mathrm{L}$ color-developing solution containing $1.5 \mathrm{mg} / \mathrm{mL}$ o-phenylenediamine and $0.008 \%$ $\mathrm{H}_{2} \mathrm{O}_{2}$ was added to each well. The reaction was stopped by addition of $50 \mu \mathrm{L} 2 \mathrm{M} \mathrm{H}_{2} \mathrm{SO}_{4}$ per well when the $2000 \mathrm{ng} / \mathrm{mL}$ standard was pale in color, and the $0 \mathrm{ng} / \mathrm{mL}$ standard was deeply colored. Color development on each well was recorded using an ELISA Reader (model EL310, Bio-TEK, Winooski, VT) at an optical density of $490 \mathrm{~nm}$. Hormone contents were calculated from the mean of three biological replicates.

\section{Data analysis}

Percentage data was arcsine square root transformed. One-way analyses of variance (ANOVA) were used to test for significant differences among developmental stages. Variance was analyzed using the least significant difference (LSD) test. Pearson correlation and curve estimation analyses were performed. $\mathrm{P} \leq 0.05$ was considered to be statistically significant. 


\section{RESULTS}

\section{Cell length variation during development}

The meristematic nature of cell division in plants imposes a unique set of constraints on cell elongation and plant growth during development (Jacobs, 1997). Here, we sought to elucidate the relationship between cell division and cell elongation in bamboo by analysis of cell lengths at different developmental stages in three regions of a growing culm (Figure 1B and C). Cell lengths in the middle internode increased continuously from G1 to G9 stages (Figure 2B); this effect was not present in the basal and top internodes (Figure 2A and $C$ ). In the top internode, cell length changes from the G1 to G8 stages were small, although cell lengths at G9 were larger than those of earlier stages. The cell lengths in the middle internode at different developmental stages were analyzed by a normal distribution test, which demonstrated that cell lengths showed a normal distribution when the bamboo shoot had just emerged (G1 and G2). As cell elongation accelerated, cell lengths deviated from a normal distribution (G3-G5). Although a return to a normal distribution occurred at G6, it then deviated from this at G7 and G8. In the terminal stage (G9), which had slow cell elongation, cell lengths again followed a normal distribution.
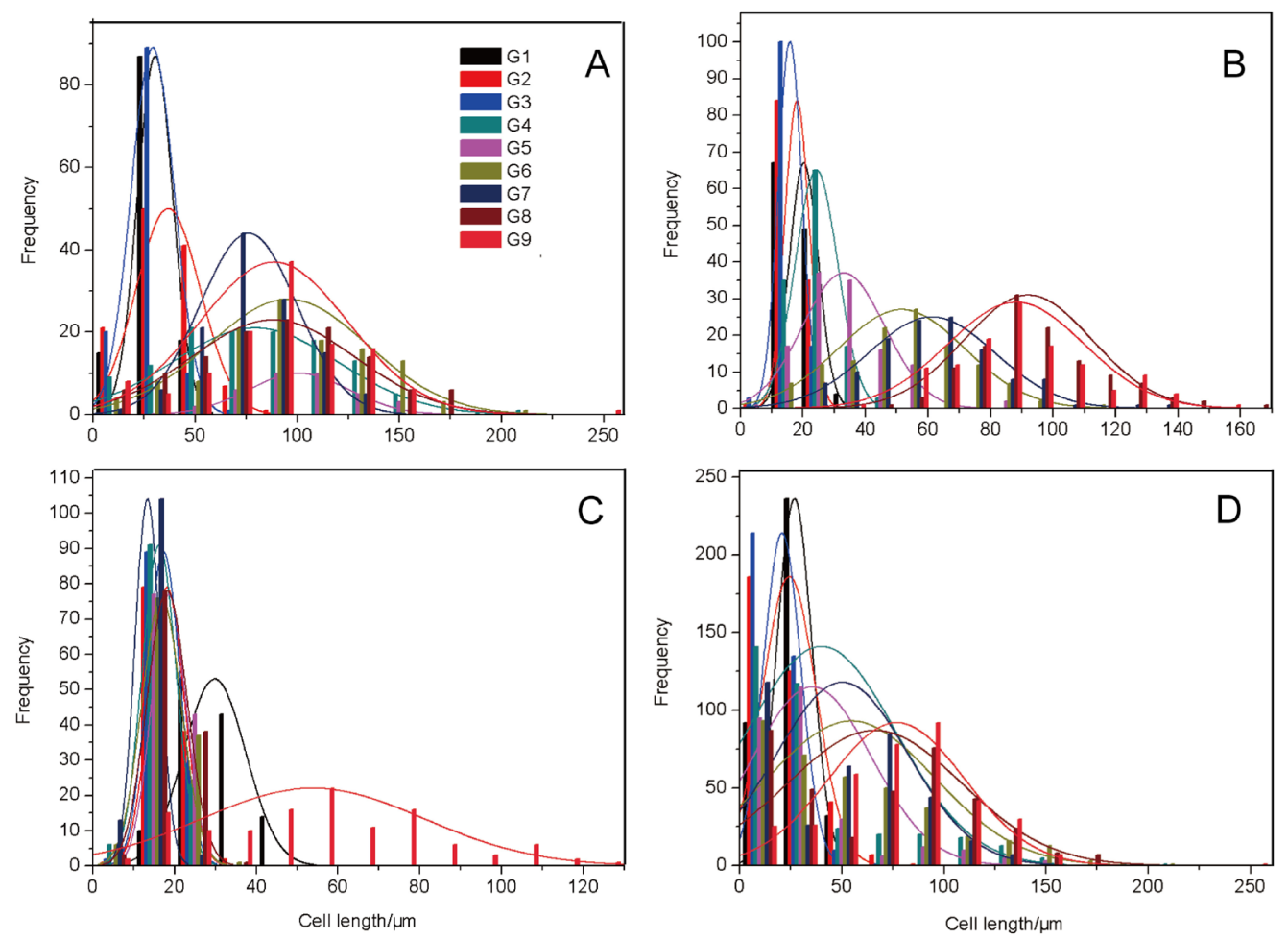

Figure 2. Distribution of cell lengths at different developmental stages and from different regions of the culm. A. B. and C. represent basal, middle, and top internodes, respectively. D. Indicates the combined data from basal, middle, and top internodes. $\mathrm{N}=1000$. 


\section{Variations in cell length and cell division rates during development}

The rate of cell proliferation was estimated by counting the number of cell nuclei in each transverse section. Cell lengths and frequencies of nuclei were compared at different stages and in different parts of the culm to provide a temporal and spatial profiling of culm elongation. At all developmental stages except G1, cell lengths in the basal and middle internodes were greater than in the top internodes; cell lengths in basal internodes were larger than in middle internodes before G8. Mean cell length in the basal internodes at G1 was $30.51 \mu \mathrm{m}$; it then peaked at G2 and G5 with mean lengths of 35.69 and $100.73 \mu \mathrm{m}$, respectively; mean cell length decreased to $76.14 \mu \mathrm{m}$ at G7 but increased again at G8 and G9. Mean cell length in the top internodes at G1 was $29.84 \mu \mathrm{m}$, decreased to $18.12 \mu \mathrm{m}$ at G2, and then rose to its highest value at G9 (Figure 3A).
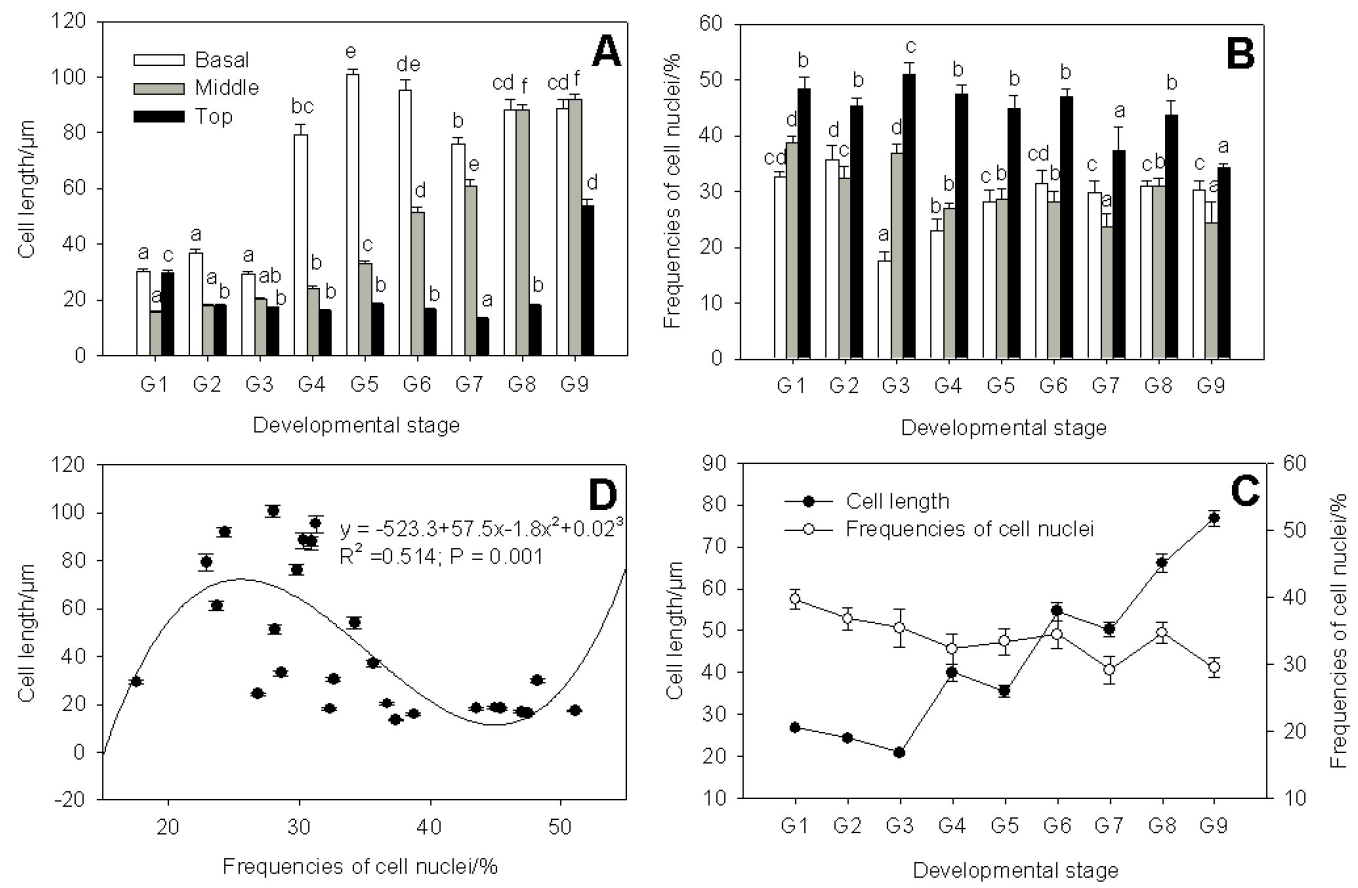

Figure 3. Changes in cell length and frequencies of cell nuclei during culm development. Basal, middle, and top represent basal, middle, and top internodes, respectively. Bars indicate SE. A. Cell lengths at different developmental stages and in different regions of the culm. $N=1000$. B. Frequency of cell nuclei at different developmental stages and in different regions of the culm. $\mathrm{N}=1000$. C. In order to produce a temporal profile of culm elongation, the data for the different regions of the culm were combined and the values at different developmental stages were analyzed. $\mathrm{N}=$ 3000. D. Data fitting of cell lengths and frequency of cell nuclei. $N=1000$. Different letters on a column with the same shading indicate significant differences at $\mathrm{P} \leq 0.05$ according to the LSD test.

The frequency of cell nuclei in sections from the top internodes was higher than in the middle and basal internodes during all stages. All three regions of the culm showed changes in cell nucleus frequencies during development with three peaks. In the middle and top internodes, the peaks appeared at G3, G6, and G8, but in the basal internode the peaks occurred at G2, G6, and 
G8 (Figure 3B). In order to further analyze temporal changes during culm elongation, we combined the values from each region at the different developmental stages. As shown in Figure $3 C$, cell length increased in an essentially linear manner from G1 to G9 stages, whereas, the frequency of cell nuclei fell during development. The relationship between cell length and frequency of cell nuclei fitted a cubic curve equation (Figure 3D).

Our results indicated that cell division and cell elongation simultaneously influenced internode elongation; the former was predominant in initial stages while the latter was predominant in late stages. Cell elongation initiated earlier in basal internodes compared to middle and top internodes; and at late stages, cell lengths in middle internodes exceeded those of basal internodes. As the majority of cells in the top internodes were mitotically active, the increment in cell lengths of the top internodes was not obvious before G9.

\section{Hormonal change during different developmental stages and portions}

The ZR concentration in the three culm regions showed a bimodal variation pattern during development (Figure 4A). In all three regions, a peak occurred at G3, and a second peak occurred at G7, G8, and G6 in the basal, middle, and top internodes, respectively. ZR concentrations in the basal and middle internodes varied significantly during development $(P<0.05)$. At each developmental stage, the ZR concentration of the basal internode was always lower than that of the top internode. ZR concentration increased to similar extents in basal, middle, and top internodes at G1 to G3; thereafter, the magnitude of increases at G4 to G9 varied among the culm regions (Figure 4A).
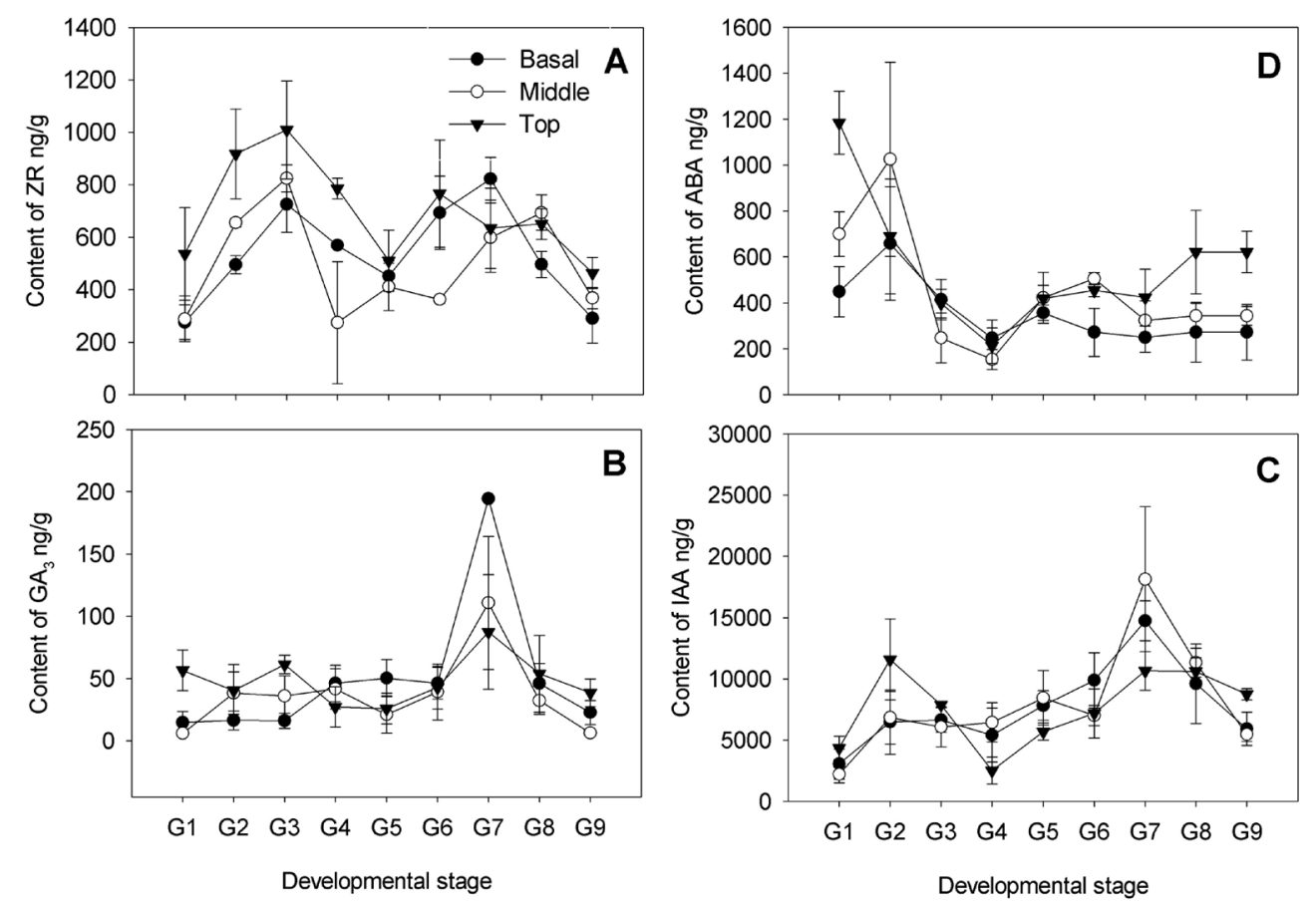

Figure 4. Changes in endogenous hormone concentrations during culm development. Basal, middle, and top represent basal, middle, and top internodes, respectively. Bars indicate SE $(\mathrm{N}=9)$. 
There was evidence of bimodal variation in $\mathrm{GA}_{3}$ concentrations during development in the three culm regions. In all three regions, an initial peak appeared at G5, G4, and G3 (50.32, 41.68, and $61.25 \mathrm{ng} / \mathrm{g}$, respectively), and a second peak appeared at $\mathrm{G} 7$ (194.43, 110.75, and $87.45 \mathrm{ng} / \mathrm{g}$, respectively). The $\mathrm{GA}_{3}$ concentration in the basal internodes varied significantly among different developmental stages; the concentration at $G 7$ was higher than at any other stage $(P<0.05)$. At $\mathrm{G} 1$ to $\mathrm{G} 3$, the highest $\mathrm{GA}_{3}$ concentration was found in the top internodes. Subsequently, at $\mathrm{G} 4$ to $\mathrm{G} 7$, the highest $\mathrm{GA}_{3}$ concentration appeared at basal internodes, and the highest $\mathrm{GA}_{3}$ concentration appeared at top internodes again in the late stages at G8 and G9 (Figure 4B). IAA concentrations were considerably higher than those of the other three hormones. During development, the IAA concentrations in the three culm regions showed bimodal variation. Two peaks were present in all three internodes at $\mathrm{G} 2$ and $\mathrm{G} 7$. The IAA concentrations in all three regions varied significantly during development $(P<0.05)$ (Figure 4C).

ABA concentrations in the three culm regions were high at $\mathrm{G} 1$ and $\mathrm{G} 2$ stages, then decreased to a low level. In the middle and top internodes, ABA concentrations varied significantly during development $(P<0.05)$ (Figure 4D).

The ratio between growth promoting hormones (IAA, GA $A_{3}$, and $Z R$ ) and the growth inhibitory hormone (ABA) was analyzed. The data from all three culm regions were combined for the analysis, which indicated that the ratio showed two peaks at G4 and G7 (Figure 5). The G4 stage corresponds to the initial phase of significant cell elongation in the basal internode, and the G7 stage corresponds to a phase of significant cell elongation in the middle internode (Figure 3A). In addition, we observed that lignification of fiber cells occurred after the G7 stage. This indicates that the hormonal equilibrium might regulate the elongation and maturation of culms.

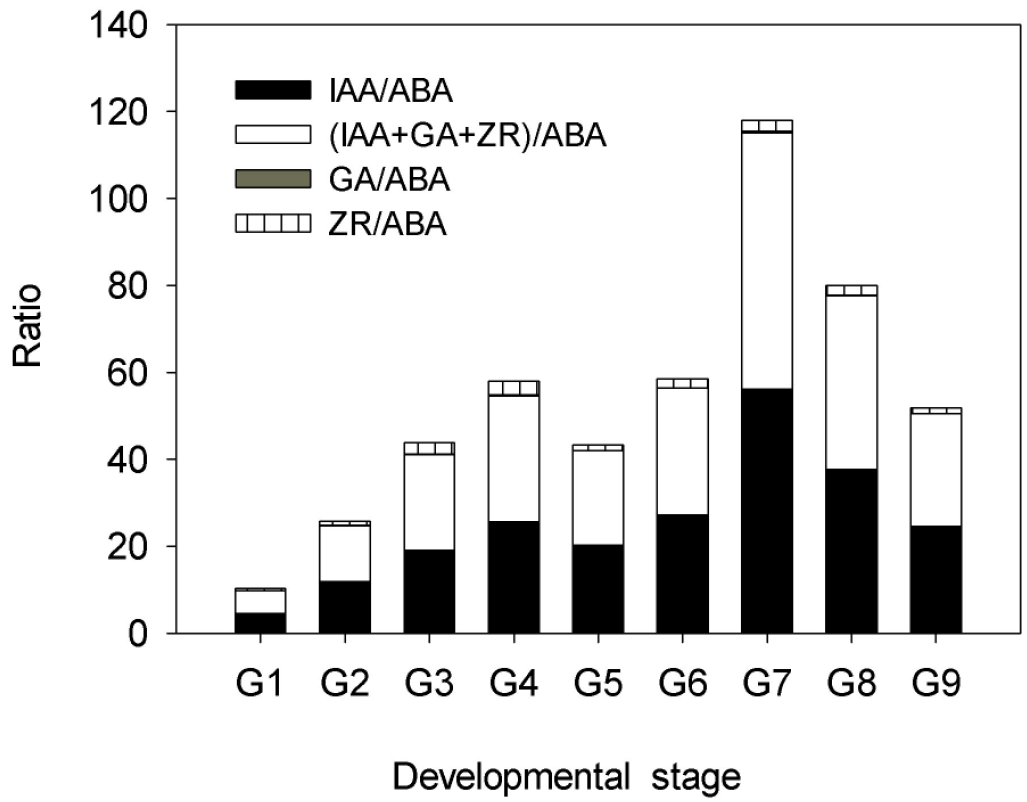

Figure 5. Ratio of the four hormones at different developmental stages. Bars with the same shading represent the mean of the three regions (basal, middle, and top internodes) at the same developmental stage. 


\section{Relationship of endogenous hormones and internode development}

The relationships among the four endogenous hormones, cell length and frequency of cell nuclei were analyzed. $\mathrm{GA}_{3}$ concentration was positively correlated with IAA and ZR concentration $(P<0.05)$. The frequency of cell nuclei was positively correlated with ZR and ABA concentration, and negatively correlated with $\mathrm{GA}_{3}$ and IAA; by contrast, cell length showed a positive correlation. The frequency of cell nuclei was negatively correlated with IAA/ABA, whereas cell length showed a positive correlation $(P<0.05)$ (Table 1$)$. In addition, the relationships between frequency of cell nuclei and ZR content, and between cell length and IAA/ABA fitted quadratic equations (Figure 6).

\section{Table 1. Correlations of concentration of endogenous hormones, cell length, and frequency of cell nuclei.}

\begin{tabular}{|c|c|c|c|c|c|c|}
\hline & ZR & ABA & $\mathrm{GA}_{3}$ & IAA & IAA/ABA & $\left(\mathrm{IAA}+\mathrm{ZR}+\mathrm{GA}_{3}\right) / \mathrm{ABA}$ \\
\hline ORCN & $0.420^{*}$ & 0.378 & -0.030 & -0.204 & $-0.393^{*}$ & -0.379 \\
\hline $\mathrm{CL}$ & -0.239 & $-0.399^{*}$ & 0.157 & 0.281 & $0.518^{* *}$ & $0.512^{* *}$ \\
\hline IAA & 0.375 & -0.177 & $0.712^{\star \star}$ & & & \\
\hline $\mathrm{GA}_{3}$ & $0.393^{*}$ & -0.148 & & & & \\
\hline $\mathrm{ABA}$ & -0.021 & & & & & \\
\hline
\end{tabular}

Pearson correlation was used: * and ${ }^{* *}$ indicate significant correlations at the 0.05 and 0.01 level, respectively (2-tailed). $\mathrm{N}=9$. $\mathrm{CL}$, cell length. ORCN,frequency of cell nuclei.
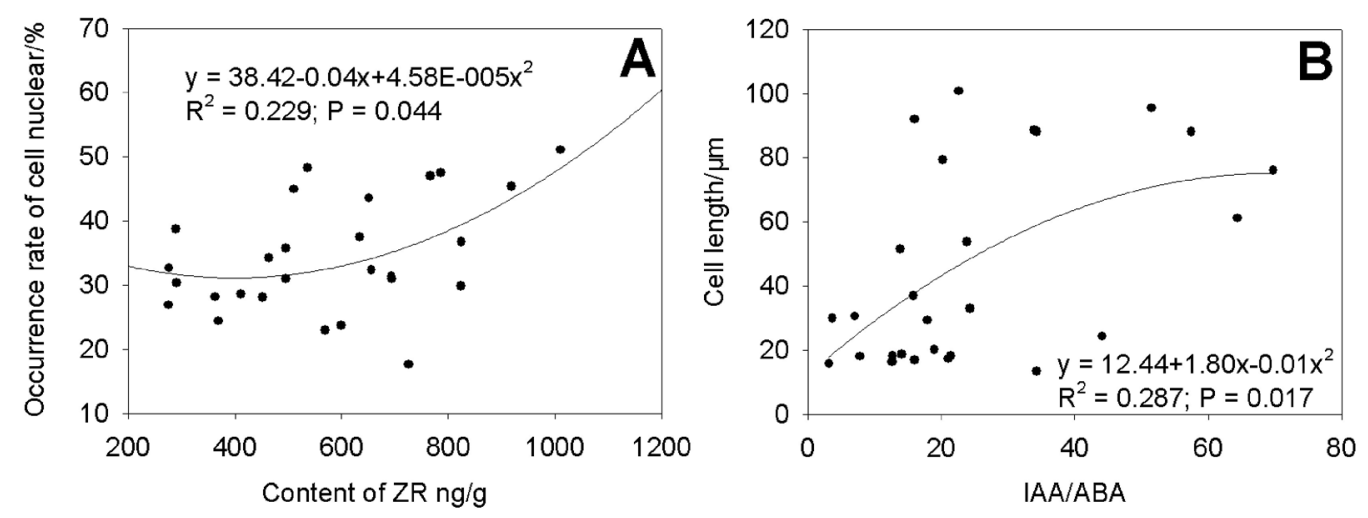

Figure 6. Data fitting of the variations in endogenous hormones and internode development.

\section{DISCUSSION}

Growth rate is regulated by the combined activity of two linked processes, expansion and cell production. According to the study of Beemster and Baskin (1998), the acceleration of root elongation in Arabidopsis thaliana is caused by an increasingly longer growth zone accompanied by a nearly proportional increase in the rate of cell production. In maize leaves, cell division is accompanied by cell expansion, with both processes partly overlapping in time and space. Cells are continuously produced in the meristematic region near the leaf base and expand without division in distal regions of the elongating zone, while they are pushed forward by younger cells. Faster cell division rates are compensated by faster cell elongation and displacement rates, resulting in invariant profiles of cell lengths and proportions of dividing cells (Ben-Haj-Salah and Tardieu, 1995). 
However, in this study, cell length and cell division during bamboo culm development showed a significant negative correlation $(P<0.05)$. The relationship between cell length and cell division during bamboo culm development fitted a cubic curve equation. A current model for metazoan growth proposes that cell number and cell size are controlled by distinct proliferation and growth signals that negatively affect each other (Potter and Xu, 2001); when cell size increases, cell count is reduced and vice versa. This regulation ensures that induced alterations in cell proliferation are compensated by changes in cell size, resulting in little net change in final organ size. The compensation phenomenon has also been observed in plants (De Veylder et al., 2001). The results of the present study are consistent with this model.

In a growth curve analysis (total length vs time) of pedicels in A. thaliana, Bundy et al. (2012) reported that growth is exponential for the first 16 days after which it becomes linear. However, the present study in bamboo found that cell lengths in culms increased in an essentially linear manner from initial to terminal stages (Figure 3C). This difference is possibly caused by sampling strategy. Further analyses will clarify if this explanation is correct. A wide range of cell types has been shown to have a normal distribution for cell division rates during balanced growth (Kubitschek, 1966). Cell length distribution can reflect the status of cell proliferation. In this study, cell lengths deviated from a normal distribution in the intermediate stages of development, but followed normal distribution at later stages. This change might be due to a homeostatic coordination of cell elongation and division.

Plants, being sessile organisms, have evolved unique signaling mechanisms that allow rapid communication between different tissues and organs. These mechanisms include longrange effectors, such as phytohormones (Sparks et al., 2013). In most cases, the control of the cell cycle and cell proliferation and differentiation during development depends on the concerted action of plant hormones (Santner and Estelle, 2009; Peleg and Blumwald, 2011). In this study, we described the spatiotemporal variation in four endogenous hormones (IAA, GA, ZR, and ABA) in the culms of $P$. heterocycla during a single growing season. IAA has been widely reported to be involved in stem growth in many plant species. Sundberg et al. (1991) indicated that the level of endogenous IAA was related to seasonal changes in cambial activity in Pinus sylvestris. Uggla et al. (1998) suggested that the gradient in radial width IAA concentration was strongly correlated with cambial growth rate in the Scots pine, and that IAA had a role in defining the altered developmental pattern associated with latewood formation. In addition, cambial activity is associated with changes in IAA/ABA, and ABA might play a key role in vascular cambium dormancy in Eucommi aulmoides (Mwange et al., 2005). Branching of annual shoots in the common walnut (Juglans regia) is affected by IAA concentration (Solar et al., 2011). In the present study, we did not find a strong relationship between IAA concentration and cell length $(P>0.05)$, but cell length was positively correlated with IAA/ABA ( $R=0.518, P<0.01)$.

Gibberellin is involved in stem elongation in graminaceous plants (Zhu et al., 2006). For example, in rice, EUI1 encodes a putative cytochrome P450 monooxygenase, which is implicated in both gibberellin-mediated SLR1 destruction and a feedback regulation of gibberellin biosynthesis. Thus, EUI1 plays an important role in gibberellin-mediated regulation of cell elongation in the uppermost internode (Luo et al., 2006). Cosgrove (2000) indicated that treatment with gibberellin can increase the accumulation of expansin, which accelerates the growth rate of rice internodes. Kong et al. (2008) reported that endogenous IAA concentrations increase in the cambial region after gibberellins are exogenous applied. In the present study, $\mathrm{GA}_{3}$ concentration was found to be positively correlated with IAA concentration $(R=0.712, P<0.05)$. However, $G_{3}$ concentration 
was not significantly correlated with either the frequency of cell nucleior cell length $(P>0.05)$. This suggests that the changes in $\mathrm{GA}_{3}$ concentration are not sufficient to explain cell elongation during the internode development in bamboo.

Hormones do not act alone but in conjunction, or in opposition, to each other such that the final condition of growth or development represents the net effect of hormonal balance (Wilkinson et al., 2012). Auxins regulate cell division, while cytokinins act at the transition zone to control cell differentiation rate (Dello loio et al., 2007). Antagonistic interactions between auxins and cytokinins are a key determinant in the control of meristem activity (Chapman and Estelle, 2009). Furthermore, the interaction of auxins and cytokinins indirectly affects GA behavior (Moubayidin et al., 2010). In the present study, ZR concentration was shown to be positively correlated with the frequency of cell nuclei. We did not find a significant correlation between cell length and the concentrations of IAA, $G_{3}$, or ZR. Nevertheless, cell length was positively correlated with the ratio of $\left(I A A+G A_{3}+Z R\right)$ concentration to ABA concentration. Aarrouf et al. (1999) reported that elongation of the primary roots of rapeseed seedlings coincided with an increase in both IAA and ABA concentrations. Conversely, in this study, ABA concentration had a negative correlation with cell length. These results indicate that hormonal equilibrium might regulate cell division and elongation during bamboo culm development. Similarly, Kucera et al. (2005) concluded that hormonal interactions regulate the dormancy release and germination of eudicot seeds.

\section{Conflicts of interest}

The authors declare no conflict of interest.

\section{ACKNOWLEDGMENTS}

Research supported by the National Natural Science Foundation of China (\#31300501 and \#30972332), and the National Nonprofit Institute Research Grant from the Research Institute of Resources Insects, Chinese Academy of Forestry (CAFYBB2014QB020 and riricaf2013002M).

\section{REFERENCES}

Aarrouf J, Schoëvaërt D, Maldiney R and Perbal G (1999). Changes in hormonal balance and meristematic activity in primary root tips on the slowly rotating clinostat and their effect on the development of the rapeseed root system. Physiol. Plant. 105: 708-718.

Achard P, Gusti A, Cheminant S, Alioua M, et al. (2009). Gibberellin signaling controls cell proliferation rate in Arabidopsis. Curr. Biol. 19: 1188-1193.

Bartrina I, Otto E, Strnad M, Werner T, et al. (2011). Cytokinin regulates the activity of reproductive meristems, flower organ size, ovule formation, and thus seed yield in Arabidopsis thaliana. Plant Cell 23: 69-80.

Beemster GTS and Baskin TI (1998). Analysis of cell division and elongation underlying the developmental acceleration of root growth in Arabidopsis thaliana. Plant Physiol. 116: 1515-1526.

Ben-Haj-Salah H and Tardieu F (1995). Temperature affects expansion rate of maize leaves without change in spatial distribution of cell length (analysis of the coordination between cell division and cell expansion). Plant Physiol. 109: 861-870.

Bundy MGR, Thompson OA, Sieger MT and Shpak ED (2012). Patterns of cell division, cell differentiation and cell elongation in epidermis and cortex of Arabidopsis pedicels in the wild type and in erecta. Plos One 7: e46262.

Chapman EJ and Estelle M (2009). Cytokinin and auxin intersection in root meristems. Genome Biol. 10: 210.

Chen CY, Hsieh MH, Yang CC, Lin CS, et al. (2010). Analysis of the cellulose synthase genes associated with primary cell wall synthesis in Bambusa oldhamii. Phytochemistry 71: 1270-1279.

Cosgrove DJ (2000). Loosening of plant cell walls by expansins. Nature 407: 321-326.

Cui K, He C, Zhang JG, Duan AG, et al. (2012). Temporal and spatial profiling of Internode elongation-associated protein 
expression in rapidly growing culms of bamboo. J. Proteome Res. 11: 2492-2507.

Davies PJ (2010). The plant hormones: their nature, occurrence, and functions. In: Plant hormones (Davies PJ, ed.). Springer, Netherlands, 1-15.

De Veylder L, Beeckman T, Beemster GTS, Krols L, et al. (2001). Functional analysis of cyclin-dependent kinase inhibitors of Arabidopsis. Plant Cell 13: 1653-1668.

Dello loio R, Linhares FS, Scacchi E, Casamitjana-Martinez E, et al. (2007). Cytokinins determine Arabidopsis root-meristem size by controlling cell differentiation. Curr. Biol. 17: 678-682.

Higuchi M, Pischke MS, Mähönen AP, Miyawaki K, et al. (2004). In planta functions of the Arabidopsis cytokinin receptor family. Proc. Natl. Acad. Sci. U. S. A. 101: 8821-8826.

Jacobs T (1997). Why do plant cells divide? Plant Cell 9: 1021-1029.

Jurado S, Abraham Z, Manzano C, López-Torrejón G, et al. (2010). The Arabidopsis cell cycle F-box protein SKP2A binds to auxin. Plant Cell 22: 3891-3904.

Kong L, Abrams SR, Owen SJ, Graham H, et al. (2008). Phytohormones and their metabolites during long shoot development in Douglas-fir following cone induction by gibberellin injection. Tree Physiol. 28: 1357-1364.

Kubitschek HE (1966). Normal distribution of cell generation rates. Nature 209: 1039-1040.

Kucera B, Cohn MA and Leubner-Metzger G (2005). Plant hormone interactions during seed dormancy release and germination. Seed Sci. Res. 15: 281-307.

Luo AD, Qian Q, Yin HF, Liu XQ, et al. (2006). EUl1, encoding a putative cytochrome P450 monooxygenase, regulates internode elongation by modulating gibberellin responses in rice. Plant Cell Physiol. 47: 181-191.

Magel E, Kruse S, Lütje G and Liese W (2006). Soluble carbohydrates and acid invertases involved in the rapid growth of developing culms in Sasa palmata (Bean) Camus. Bamboo Sci. Cult. 19: 23-29.

Moubayidin L, Perilli S, Dello loio R, Di Mambro R, et al. (2010). The rate of cell differentiation controls the Arabidopsis root meristem growth phase. Curr. Biol. 20: 1138-1143.

Mwange KNK, Hou HW, Wang YQ, He XQ, et al. (2005). Opposite patterns in the annual distribution and time-course of endogenous abscisic acid and indole-3-acetic acid in relation to the periodicity of cambial activity in Eucommia ulmoides Oliv. J. Exp. Bot. 56: 1017-1028.

Nemhauser JL, Hong FX and Chory J (2006). Different plant hormones regulate similar processes through largely nonoverlapping transcriptional responses. Cell 126: 467-475.

Nishimura C, Ohashi Y, Sato S, Kato T, et al. (2004). Histidine kinase homologs that act as cytokinin receptors possess overlapping functions in the regulation of shoot and root growth in Arabidopsis. Plant Cell 16: 1365-1377.

Peleg Z and Blumwald E (2011). Hormone balance and abiotic stress tolerance in crop plants. Curr. Opin. Plant Biol. 14: $290-295$.

Peng Z, Lu Y, Li L, Zhao Q, et al. (2013). The draft genome of the fast-growing non-timber forest species moso bamboo (Phyllostachys heterocycla). Nat. Genet. 45: 456-461.

Peng ZH, Lu TH, Li LB, Liu XH, et al. (2010). Genome-wide characterization of the biggest grass, bamboo, based on 10,608 putative full-length cDNA sequences. BMC Plant Biol. 10: 116.

Pérez-Jiménez M, Cantero-Navarro E, Pérez-Alfocea F, Le-Disquet I, et al. (2014). Relationship between endogenous hormonal content and somatic organogenesis in callus of peach (Prunus persica L. Batsch) cultivars and Prunus persica $\times$ Prunus dulcis rootstocks. J. Plant Physiol. 171: 619-624.

Potter CJ and Xu T (2001). Mechanisms of size control. Curr. Opin. Genet. Dev. 11: 279-286.

Santner A and Estelle M (2009). Recent advances and emerging trends in plant hormone signalling. Nature 459: 1071-1078.

Solar A, Osterc G, Štampar F and Kelc D (2011). Branching of annual shoots in common walnut (Juglans regia L.) as affected by bud production and indol-3-acetic acid (IAA) content. Trees 25: 1083-1090.

Sparks E, Wachsman G and Benfey PN (2013). Spatiotemporal signalling in plant development. Nat. Rev. Genet. 14: 631-644.

Sundberg B, Little C, Cui K and Sandberg G (1991). Level of endogenous indole-3-acetic acid in the stem of Pinus sylvestris in relation to the seasonal variation of cambial activity. Plant Cell Environ. 14: 241-246.

Uggla C, Mellerowicz EJ and Sundberg B (1998). Indole-3-acetic acid controls cambial growth in Scots pine by positional signaling. Plant Physiol. 117: 113-121.

Uggla C, Magel E, Moritz T and Sundberg B (2001). Function and dynamics of auxin and carbohydrates during earlywood/ latewood transition in Scots pine. Plant Physiol. 125: 2029-2039.

Wang H, Zhou Y, Gilmer S, Whitwill S, et al. (2000). Expression of the plant cyclin-dependent kinase inhibitor ICK1 affects cell division, plant growth and morphology. Plant J. 24: 613-623.

Wilkinson S, Kudoyarova GR, Veselov DS, Arkhipova TN, et al. (2012). Plant hormone interactions: innovative targets for crop breeding and management. J. Exp. Bot. 63: 3499-3509.

Yang J, Zhang J, Wang Z, Zhu Q, et al. (2001). Hormonal changes in the grains of rice subjected to water stress during grain filling. Plant Physiol. 127: 315-323. 